\title{
Evaluasi Tarif Pelayanan Badan Layanan Umum dengan Metode Unit Cost Pada Universitas Islam Negeri Imam Bonjol Padang
}

\author{
Ramayani Eka Putri ${ }^{1}$, Suhairi $^{2}$, Nini Syofriyeni ${ }^{3}$ \\ ${ }_{1,2,3}$ Program Pascasarjana Universitas Andalas \\ Correspondence email: ramayaniekaputri@gmail.com ${ }^{1 *}$, suhairi1908@gmail.com ${ }^{2}$, ninisyofriyeni1@gmail.com ${ }^{3}$
}

\begin{abstract}
Abstrak. Penelitian ini merupakan penelitian terapan yang bertujuan untuk menghitung unit cost per output kegiatan layanan pada Pascasarjana UIN Imam Bonjol Padang menggunakan metode Activity Based Costing, dan membandingkan hasil perhitungan unit cost untuk setiap tarif layanan BLU UIN Imam Bonjol Padang yang sedang berlaku serta memberikan rekomendasi untuk evaluasi tarif yang relevan dengan kondisi UIN Imam Bonjol Padang sekarang. Diharapkan penelitian ini dapat memberikan masukan yang berharga sehingga dapat diterapkan tarif pelayanan yang relevan dengan perkembangan UIN Imam Bonjol Padang dan dapat menjadi salah satu acuan untuk melakukan perhitungan tarif pelayanan demi meningkatkan tingkat efisiensi dan efektivitas pengelolaan keuangan Negara. Design penelitian yang digunakan adalah metode deskriptif kuantitatif. Data yang digunakan dalam penelitian ini adalah data sekunder berupa data anggaran dan realisasi belanja yang dikeluarkan untuk setiap kegiatan pelayanan. Hasil penelitian menunjukkan bahwa hampir keseluruhan unit cost pelayanan pada program Pascasarjana UIN Imam Bonjol Padang ternyata lebih besar dari tarif yang berlaku (underrated). Hal ini menunjukkan bahwa tarif pelayanan BLU UIN Imam Bonjol Padang sudah tidak relevan lagi. UIN Imam Bonjol Padang perlu melakukan evaluasi tarif pelayanan agar dapat mengoptimalkan pengelolaan keuangan, sehingga pelayanan BLU dapat semakin ditingkatkan.
\end{abstract}

Kata kunci: Activity Based Costing; Metode Unit Cost; Tarif Pelayanan Badan Layanan Umum.

\begin{abstract}
This study is an applied research which aims to calculate the unit cost per service activity output at the UIN Imam Bonjol Padang Postgraduate program using the Activity Based Costing method, and compare the results of the unit cost calculation for each of the current Imam Bonjol UIN BLU service rates and provide recommendations for evaluation of rates relevant to UIN Imam Bonjol Padang's current condition. It is hoped that this research can provide valuable input so that service rates that are relevant to the development of Imam Bonjol Padang UIN can be applied and can be one of the references for calculating service rates in order to increase the level of efficiency and effectiveness of State financial management. The research design used is quantitative descriptive method. The data used in this study are secondary data in the form of budget data and expenditure expenditures released for each service activity. The results showed that almost the entire unit cost of service in the UIN Imam Bonjol Padang Postgraduate program turned out to be higher than the applicable rate (underrated). This shows that BLU UIN Imam Bonjol Padang's service rates is no longer relevant. UIN Imam Bonjol Padang needs to evaluate service rates in order to optimize financial management, so BLU services can be further improved.
\end{abstract}

Keywords: Activity Based Costing; Public Service Agency Rates; Unit cost Method.

\section{PENDAHULUAN}

Reformasi keuangan negara mengamanatkan pergeseran sistem penganggaran dari tradisional menjadi pengganggaran berbasis kinerja, agar penggunaan dana pemerintah menjadi berorientasi pada hasil sebagaimana dijelaskan dalam penjelasan Undang-Undang No. 17 Tahun 2003 tentang Keuangan Negara. Undang-undang ini merupakan salah satu landasan pemerintah untuk membentuk Badan Layanan Umum (BLU) dalam rangka meningkatkan pelayanan publik demi kesejahteraan masyarakat. Dalam menjalankan amanat tersebut, diperlukan tambahan dana dari masyarakat karena keterbatasan sumber daya yang ada.

Dalam pasal 1 Undang-Undang No.1 Tahun 2004 tentang Perbendaharaan Negara, disebutkan bahwa Badan Layanan Umum, yang selanjutnya disebut BLU, adalah instansi di lingkungan Pemerintah yang dibentuk untuk memberikan pelayanan kepada masyarakat berupa penyediaan barang dan/atau jasa yang dijual tanpa mengutamakan mencari keuntungan dan dalam melakukan kegiatannya didasarkan pada prinsip efesiensi dan produktivitas. Adanya BLU menjadikan pemerintah lebih fleksibel dalam mengelola keuangannya, sehingga memungkinkan pemerintah untuk berbisnis dan berwirausaha namun tetap mengedepankan pelayanan.

Penjelasan lebih lanjut mengenai BLU juga dijelaskan pada Peraturan Pemerintah No. 23 Tahun 2005 tentang Pengelolaan Keuangan Badan Layanan Umum yang memberikan arahan bahwa pola BLU diberikan kepada satuan-satuan kerja Pemerintah yang melaksanakan tugas operasional pelayanan publik (seperti layanan kesehatan, pendidikan, pengelolaan kawasan dan lisensi) untuk membedakan dari fungsi pemerintah sebagai regulator dan penentu kebijakan. Saat ini jumlah Satuan Kerja di Indonesia yang ditetapkan sebagai BLU ada sebanyak 157 BLU. Sebagian besar dari jumlah tersebut merupakan lembaga satuan pendidikan. Kebijakan BLU pada lembaga pendidikan seiring dengan semakin meningkatnya 
tuntutan di era globalisasi sekarang ini. Persaingan tidak hanya terjadi di lingkungan lembaga swasta, namun juga pemerintahan. Perguruan tinggi sebagai lembaga penyelenggara pendidikan tinggi di Indonesia mengalami banyak perubahan dan tantangan. Revolusi digital, tingginya tuntutan akuntabilitas dan keharusan untuk melakukan pengendalian biaya serta mewujudkan pendidikan tinggi yang berkualitas secara bersamaan merupakan beberapa tantangan yang harus dihadapi oleh institusi perguruan tinggi (Ismail, 2010).

Adanya kebijakan BLU pada lembaga pendidikan juga salah satu upaya dalam rangka meningkatkan proses manajemen yang berbasis pada pelayanan dan kualitas kerja serta pengembangan keilmuan yang dapat menghasilkan pendidikan yang bermutu. Hal tersebut tertuang dalam UU No. 12 Tahun 2012 tentang Pendidikan Tinggi. Penyelenggaraan kebijakan diberikan secara selektif berdasarkan evaluasi kinerja oleh Menteri. Berdasarkan Keputusan Menteri Keuangan Nomor 386/KMK.05/2015 yang ditetapkan di Jakarta pada tanggal 6 Maret 2015, Institut Agama Islam Negeri Imam Bonjol Padang (IAIN Imam Bonjol Padang) menjadi salah satu instansi pemerintah yang mendapatkan mandat untuk menerapkan Pengelolaan Keuangan Badan Layanan Umum (PK-BLU).

Sebagai bagian dari institusi pendidikan tinggi di Indonesia, IAIN Imam Bonjol Padang kedepan dikelola berdasarkan pada tiga orientasi dasar yakni kualitas, professionalitas dan akuntabilitas. Tuntutan tersebut menjadi semakin meningkat lagi setelah IAIN Imam Bonjol Padang beralih status menjadi salah satu perguruan tinggi negeri di Indonesia yaitu Universitas Islam Negeri Imam Bonjol Padang (UIN Imam Bonjol Padang). Peralihan status ini diresmikan pada tahun 2017 berdasarkan Perpres No. 35 tahun 2017 tentang UIN Imam Bonjol Padang. Kedua perubahan besar tersebut akan membawa banyak perubahan di berbagai aspek dalam lingkungan satuan kerja BLU UIN Imam Bonjol Padang.

Menindaklanjuti Keputusan Menteri Keuangan dan isu serta fenomena di atas, UIN Imam Bonjol Padang diwajibkan untuk mengajukan usulan tarif layanan jasa pendidikan dan jasa lainnya yang dikembangkan oleh UIN Imam Bonjol Padang dengan berpedoman kepada Peraturan Pemerintah Nomor 23 Tahun 2005 dan sudah diperbaharui menjadi Peraturan Pemerintah Nomor 74 Tahun 2012. Salah satu nomenklatur menyebutkan bahwa layanan tarif harus mempertimbangkan atau menganalisis empat faktor yaitu: (1) faktor kontinuitas dan pengembangan layanan, (2) faktor daya beli masyarakat, (3) faktor rasa keadilan dan kepatutan dan (4) kompetisi yang sehat.

Sejalan dengan tuntutan responsif di atas UIN Imam Bonjol Padang berusaha untuk meningkatkan proses manejemen yang berbasis pada pelayanan dan kualitas kinerja serta atas pertimbangan kebutuhan peningkatan responsifitas dan peluang yang dimungkinkan. Maka, UIN Imam Bonjol Padang telah menyusun usulan tarif layanan untuk mendapatkan persetujuan ketetapan menteri keuangan.

Saat ini UIN Imam Bonjol Padang menggunakan tarif pelayanan akademik yang diperhitungkan dengan metode unit cost. Perhitungan tersebut dilakukan dengan merujuk kepada realisasi anggaran tahun 2014. Agar UIN Imam Bonjol Padang dapat meningkatkan eksistensinya dalam dunia pendidikan Indonesia, UIN Imam Bonjol Padang harus bisa lebih baik mengelola keuangannya dari tahun ke tahun dengan memanfaatkan potensi yang ada untuk peningkatan pendapatan BLU, sekaligus mengatasi kendala-kendala yang ada.

Dalam beberapa tahun UIN Imam Bonjol Padang cukup mampu menjaga kestabilan penerimaannya dengan tetap mem- pertimbangkan faktor kontinuitas dan pengembangan layanan, hal tersebut dapat dilihat pada tabel 1 dan 2. Tabel 1 menunjukkan target dan realisasi penerimaan yang bersumber dari pendapatan negara bukan pajak (PNBP) di UIN Imam Bonjol Padang dan tabel 2 menunjukkan proyeksi atau estimasi penerimaan PNBP tiga tahun kedepan.

Tabel 1. Realisasi Pendapatan PNBP Keuangan UIN Imam Bonjol Padang Tahun 2010-2015

\begin{tabular}{ccccc}
\hline No. & Tahun & Pagu & Realisasi & Persentasi \\
\hline 1 & 2010 & 12.918 .054 .000 & 12.036 .583 .297 & $93,18 \%$ \\
2 & 2011 & 16.328 .420 .000 & 14.077 .707 .730 & $86,22 \%$ \\
3 & 2012 & 16.788 .321 .000 & 15.383 .384 .878 & $91,63 \%$ \\
4 & 2013 & 20.298 .812 .000 & 17.437 .072 .697 & $85,90 \%$ \\
5 & 2014 & 24.131 .671 .000 & 17.822 .413 .340 & $73,98 \%$ \\
6 & 2015 & $21,809,501,000$ & 20.073 .594 .685 & $92,04 \%$ \\
\hline
\end{tabular}

Sumber : Bagian Keuangan UIN Imam Bonjol Padang

Berdasarkan tabel di atas dapat dipahami bahwa pendapatan PNBP keuangan UIN Imam Bonjol Pa0dang mengalami peningkatan yang signifikan dari tahun ke tahun. Hal ini disebabkan karena peminat/calon mahasiswa yang selalu meningkat. Peningkatan yang sangat tajam terjadi pada tahun 2015, karena IAIN Imam Bonjol Padang berkonversi menjadi Universitas Islam Negeri (UIN) tahun 2016.

Tabel 2 menunjukkan proyeksi penerimaan PNBPBLU UIN Imam Bonjol Padang untuk empat tahun ke depan terhitung mulai tahun 2016 sampai tahun 2019. Proyeksi ini didasarkan pada proyeksi jumlah calon mahasiswa dan mahasiswa dikaitkandengan tarif layanan. Selain itu juga ditambah penerimaan kerjasama dengan pihak lain.

Tabel 2. Proyeksi Penerimaan PNBP Keuangan UIN Imam Bonjol Padang Tahun 2016-2019

\begin{tabular}{cccc}
\hline No. & Tahun & Preyeksi Penerimaan & Persentase Kenaikan \\
\hline 1 & 2016 & 34.294 .239 .900 & $17,90 \%$ \\
2 & 2017 & 39.222 .062 .400 & $14,30 \%$ \\
3 & 2018 & 46.536 .860 .150 & $18,60 \%$ \\
4 & 2019 & 54.027 .714 .288 & $16,10 \%$ \\
\hline
\end{tabular}

Sumber : Bagian Kelangan UIN Imam Bonjol Padang 
Berdasarkan tabel 2 di atas, proyeksi penerimaan PNBP-BLU dari tahun 2016 sampai tahun 2019 diproyeksikan naik sebesar 17,9\%. Kenaikan itu didasarkan dari proyeksi jumlah calon mahasiswa yang mendaftar untuk ikut seleksi ujian masuk dan jumlah mahasiswa yang diterima. Asumsi kenaikan jumlah mahasiswa didasarkan pada perkembangan di masa depan terutama ketika terjadi konversi UIN Imam Bonjol Padang menjadi Universitas Islam Negeri (UIN). Ketika UIN Imam Bonjol Padang telah menjadi Universitas Islam Negeri (UIN), maka akan membuka studi baru baik di bawahfakultas yang baru maupun di fakultas yang sudah ada dan dari optimalisasi unit bisnis yang dikembangkan selama ini.

Adapun potensi yang dapat diidentifikasi oleh UIN Imam Bonjol Padang, sehubungan dengan peningkatan pendapatannya terlihat dari peningkatan jumlah calon mahasiswa yang mendaftar dalam 5 tahun terakhir. Hal ini dapat diperkirakan terjadi karena beberapa hal, antara lain 1) posisi UIN Imam Bonjol Padang yang strategis di Ibukota Provinsi, sehingga dapat dengan mudah di akses, 2) bertambah banyaknya pilihan program studi yang ditawarkan oleh UIN Imam Bonjol Padang, dan 3) biaya pendidikan di UIN Imam Bonjol Padang yang sangat terjangkau.Beberapa hal tersebut sangat memungkinkan untuk meningkatkan daya jual UIN Imam Bonjol Padang di masyarakat.

Daya beli masyarakat salah satu indikatornya dapat diukur melalui kemauan masyarakat untuk menggunakan layanan jasa pendidikan yang disediakan oleh UIN Imam Bonjol Padang.Kemauan masyarakat untuk menggunakan layanan jasa pendidikan UIN Imam Bonjol Padang dapat dilihat dari jumlah pendaftar seleksi ujian masuk.

Tabel 3. Data Jumlah dan Biaya Pendaftar Seleksi Ujian Masuk Program Magister (S.2) Tahun Akademik 2010-2015

\begin{tabular}{|c|c|c|c|c|c|}
\hline \multirow{2}{*}{ No. } & \multirow{2}{*}{ Tahun Akademik } & \multicolumn{3}{|c|}{ Biaya } & \multirow{2}{*}{ Trend (\%) } \\
\hline & & Peserta & (a) & Total & \\
\hline 1 & $2010 / 2011$ & 177 & 300.000 & 53.100 .000 & 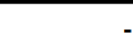 \\
\hline 2 & 2011/2012 & 252 & 300.000 & 75.600 .000 & $42 \%$ \\
\hline 3 & $2012 / 2013$ & 339 & 300.000 & 101.700 .000 & $35 \%$ \\
\hline 4 & 2013/2014 & 207 & 250.000 & 51.750 .000 & $-39 \%$ \\
\hline 5 & $2014 / 2015$ & 274 & 250.000 & 68.500 .000 & $32 \%$ \\
\hline 6 & $2015 / 2016$ & 242 & 250.000 & 60.500 .000 & $-12 \%$ \\
\hline
\end{tabular}

Sumber : Bagian Akademik dan Kemahasiswaan UIN Imam Bonjol Padang

Berdasarkan tabel 3 menyatakan bahwa trend jumlah masyarakat mendaftar dari tahun ke tahun mengalami fluktuasidari tahun 2010/2011 sampai tahun 2012/2013 mengalami kenaikan signifikan. Pada tahun 2013/2014 terjadi penurunan, namun tiga tahun berikutnya terus mengalami kenaikan.
Tabel 4 menunjukkan data pendaftar seleksi ujian masuk program doktor S.3 pada program pascasarjana UIN Imam Bonjol Padang lima tahun terakhir.

Tabel 4. Data Jumlah dan Biaya Pendaftar Seleksi Ujian Masuk Program Doktor (S.3) Tahun Akademik 2010-2015

\begin{tabular}{cccccc}
\hline \multirow{2}{*}{ No. } & TahunAkademik & \multicolumn{4}{c}{ Biaya } \\
\cline { 3 - 6 } & & Peserta & $@$ & Total & Trend (\%) \\
\hline 1 & $2010 / 2011$ & 37 & 400.000 & 14.800 .000 & \\
2 & $2011 / 2012$ & 36 & 400.000 & 14.400 .000 & $-3 \%$ \\
3 & $2012 / 2013$ & 26 & 400.000 & 10.400 .000 & $-28 \%$ \\
4 & $2013 / 2014$ & 34 & 350.000 & 11.900 .000 & $31 \%$ \\
5 & $2014 / 2015$ & 15 & 350.000 & 5.250 .000 & $-56 \%$ \\
6 & $2015 / 2016$ & 28 & 350.000 & 9.800 .000 & $87 \%$ \\
\hline
\end{tabular}

Sumber : Bagian Akademik dan Kemahasiswaan UIN Immm Bonjol Padang

Berdasarkan tabel 4 menyatakan bahwa trend jumlah masyarakat mendaftar dari tahun 2010/2011 sampai tahun 2013/2014 mengalami kenaikan dan penurunan yang tidak signifikan, tahun 2015/2016 mengalami kenaikan.

Di samping itu, beberapa problema juga dapat diidentifikasikan. Namun permasalahan tersebut segera ditemukan solusinya misalnya sebagai berikut:

1. Ketika faktor-faktor ekonomi makro seperti kenaikan harga barang kebutuhan pokok dan turunnya daya beli masyarakat, UIN Imam Bonjol Padang menyediakan tarif terendah Uang Kuliah Tunggal (UKT), disamping memfasilitasi perolehan beasiswa dari berbagai sumber.

2. Perbedaan tarif yang diberlakukan terbuka timbulnya rasa iri dan perasaan ketidakadilan diantara mahasiswa, tapi masalah ini bisa diatasi karena UIN Imam Bonjol Padang hanya menerapkan tiga bentuk jenis UKT dengan rate yang masih terjangkau dan sosialisasi yang berkelanjutan tentang UKT tersebut.

Dalam sebuah lembaga modern pendanaan merupakan syarat mutlak terwujudnya kinerja yang memuaskan. Termasuk dalam hal ini seluruh kegiatan UIN Imam Bonjol Padang membutuhkan dukungan dana yang memadai. Aspek keuangan UIN Imam Bonjol Padang dapat diukur melalui realisasi penerimaan dan realisasi belanja.

Pendekatan perhitungan unit cost atas tarif yang sedang berlaku menggunakan pendekatan akuntansi manajemen. Tujuan pendekatan ini adalah untuk menentukan jumlah biaya yang seharusnya dikeluarkan untuk pelaksanaan penyelenggaraan pendidikan dengan terlebih dahulu mengidentifikasi komponen biaya, baik biaya langsung (direct cost) maupun biaya tidak langsung (indirect cost) dan sekaligus menentukan komponen biaya tetap dan biaya variabel dari setiap jenis layanan. 
Namun pada kenyataannya, perhitungan unit cost yang dilakukan untuk penetapan tarif tersebut belum mem- perhitungkan biaya tidak langsung yang terjadi akibat dari suatu aktivitas pelayanan akademik. Komponen biaya ini akan cukup mempengaruhi dalam besaran jumlah biaya yang dikeluarkan untuk suatu pelayanan, selanjutnya juga akan mempengaruhi jumlah penerimaan Satker BLU UIN Imam Bonjol Padang. Adanya perhitungan biaya yang tepat sebagai pertimbangan penetapan tarif pelayanan, dapat menjadi pemicu bagi peningkatan jumlah penerimaan. Sebagai Satker BLU, UIN Imam Bonjol Padang harus bisa mengoptimalkan pendapatan dengan memanfaatkan potensi-potensi yang ada.

Berdasarkan isu dan fenomena di atas, penulis tertarik untuk menganalisa tariflayanan BLU yang sudah diberlakukan dengan menghitung kembali unit cost yang harus dikeluarkan untuk pelayanan BLU. Ketertarikan tersebut dikhususkan kepada salah satu unit dalam lingkungan UIN Imam Bonjol Padang yang cukup banyak menyerap anggaran yang sumber pendanaannya berasal dari BLU, yaitu Pascasarjana. Pascasarjana adalah unit yang sangat mengandalkan dana BLU. Hal ini dikarenakan Pascasarjana tidak mendapatkan sumber dana dari dana rupiah murni.

Dalam ilmu akuntansi biaya, perhitungan unit cost dapat dilakukan dengan beberapa metode. Salah satunya adalah metode Activity Based Costing System (ABC system).Menurut Johnson dalam Setiaji (2008) ABC system merupakan suatu alternatif penentuan harga pokok produk atau jasa yang saat ini cukup dikenal dan sangat relevan. Hansen dan Mowen (2009) juga mengutarakan hal yang sama, bahwa metode $\mathrm{ABC}$ system adalah metode yang akurat dan memberikan informasi yang relevan yang sangat bermanfaat untuk pengambilan keputusan.

Sehubungan dengan itu, dalam rangka memenuhi tuntutan manajemen yang akuntabel dan transparan dalam pengelolaan keuangan, berdasarkan amanat Undang-Undang Pendidikan Tinggi pada tahun 2012 Direktorat Jenderal Pendidikan Tinggi telah menghimbau perguruan tinggi untuk menghitung unit cost dengan menggunakan metode $A B C$ system. Qayoumi dalam Fontanella, dkk (2015) menyatakan bahwa $A B C$ diyakini dapat meningkatkan akuntabilitas perguruan tinggi negeri sebagai lembaga publik. UIN Imam Bonjol Padang sebagai salah satu perguruan tinggi selayaknya juga menggunakan metode ini untuk mengevaluasi tarif layanannya kembali.

Dalam PERMENDIKBUD No. 93 Tahun 2014 $A B C$ system digunakan dalam menghitung Standar Satuan Biaya Operasional dengan model pembiayaanya itu biaya langsung dan biaya tidak langsung dalam penyelenggaraan pendidikan. UIN Imam Bonjol Padang pun belum sejalan dengan aturan ini. $A B C$ system menghitung biaya setiap aktivitas serta membebankan biaya ke objek biaya seperti produk dan jasa berdasarkan aktivitas yang dibutuhkan untuk menghasilkan tiap produk dan jasa (Horngren, 2008). Jika dalam perhitungan unit cost UIN Imam Bonjol Padang memperhitungkan semua biaya-biaya tanpa terkecuali, maka kemungkinan besar tarif yang akan berlaku lebih besar dibandingkan dengan tarif sedang berlaku. Komponen biaya tidak langsung yang tidak terhitung antara lain adalah biaya listrik, biaya penyusutan dan pemeliharaan gedung serta honor pegawai. Jika semua komponen biaya dihitung, penerimaan dapat dioptimalkan.

Penelitian ini dilakukan terkait dengan adanya perubahan-perubahan internal maupun eksternal yang terjadi di lingkungan UIN Imam Bonjol Padang dengan tujuan untuk :

1. menghitung unit cost per output kegiatan layanan pada Pascasarjana UIN Imam Bonjol Padang menggunakan metode Activity Based Costing,

2. membandingkan hasil perhitungan unit cost untuk setiap tarif layanan BLU UIN Imam Bonjol Padang yang sedang berlaku dengan perhitungan metode Activity Based Costing, dan

3. memberikan rekomendasi untuk evaluasi tarif yang relevan dengan kondisi UIN Imam Bonjol Padang sekarang.

\section{Telaah Literatur \\ Teori Pelayanan}

Berdasarkan Keputusan Menteri Pendayagunaan Aparatur Negara Nomor 63 Tahun 2003 tentang Pedoman Pelayanan Publik, pelayanan publik dapat didefinisikan sebagai rangkaian kegiatan dalam rangka pemenuhan kebutuhan pelayanan sesuai dengan peraturan perundang-undangan.

Sedangkan menurut Departemen Dalam Negeri (Pengembangan Pelayanan Terpadu Satu Pintu, 2004) bahwa pelayanan publik adalah pelayanan umum, dan definisi pelayanan umum adalah suatu proses bantuan kepada orang lain dengan cara-cara tertentu yang memerlukan kepekaan dan hubungan interpersonal tercipta kepuasan barang dan jasa. Dari uraian di atas pelayanan publik dapat di artikan sebagai aktivitas pemberian jasa baik oleh pemerintah maupun pihak swasta dengan cara-cara tertentu yang memerlukan kepekaan dan interpersonal dengan begitu tercipta suatu kepuasan barang dan jasa.

Secara garis besar jenis-jenis layanan publik menurut Kepmenpan No. 63 tahun 2003 dapat dikelompokkan menjadi tiga, yaitu : (a) Kelompok pelayanan administratif; (b) Kelompok pelayanan barang dan (c) Kelompok pelayanan jasa. Standar kualitas pelayanan sekurang-kurangnya meliputi : (a) Prosedur Pelayanan; (b) Waktu Penyelesaian; (c) Biaya Pelayanan; (d) Produk Pelayanan; (e) Penyediaan sarana dan prasarana dan (f) Kompetensi Petugas Pemberi Pelayanan Publik. 
Sedangkan standar kualitas pelayanan sekurangkurangnya meliputi:

1. Prosedur Pelayanan

Prosedur pelayanan yang dibakukan bagi pemberi dan penerima pelayanan termasuk pengaduan.

2. Waktu Penyelesaian

Waktu penyelesaian yang ditetapkan sejak saat pengajuan permohonan sampai dengan penyelesaian termasuk pengaduan.

3. Biaya Pelayanan

Biaya/tarif pelayanan termasuk rinciannya yang ditetapkan dalam proses pemberian layanan.

\section{Perguruan Tinggi}

Pengertian pendidikan tinggi tertulis dalam UU No. 12 Tahun 2012 tentang Pendidikan Tinggi pada pasal 1 ayat (1) disebutkan bahwa : "Pendidikan Tinggi adalah jenjang pendidikan setelah pendidikan menengah yang mencakup program diploma, program sarjana, program magister, program doktor, dan program profesi, serta program spesialis, yang diselenggarakan oleh perguruan tinggi berdasarkan kebudayaan bangsa Indonesia.

Dalam Peraturan Pemerintah No. 33 Tahun 1990, juga disebutkan tentang tujuan perguruan tinggi adalah menyiapkan peserta didik menjadi anggota masyarakat yang memiliki kemampuan akademik dan atau profesional yang dapat menerapkan, mengembangkan dan menyebarluaskan ilmu pengetahuan dan kesenian serta menyumbangkan untuk meningkatkan taraf kehidupan masyarakat dan memperkaya kehidupan nasional. Oleh sebab itu, untuk mencapai tujuan tersebut perguruan tinggi memiliki motto yang dikenal "Tri Darma Perguruan Tinggi" yaitu pendidikan, penelitian dan pengabdian.

Pendidikan Tinggi memiliki beberapa fungsi, sebagaimana disebutkan dalam UU No. 12 Tahun 2012 Pasal 4 bahwa pendidikan tinggi memiliki 3 (tiga) fungsi sebagai berikut:

1. Mengembangkan kemampuan dan membentuk watak serta peradaban bangsa yang bermartabat dalam rangka mencerdaskan kehidupan bangsa.

2. Mengembangkan Sivitas Akademika yang inovatif, responsif, kreatif, terampil, berdaya saing, dan kooperatif melalui pelaksanaan Tridharma, dan

3. Mengembangkan Ilmu Pengetahuan dan Teknologi dengan memperhatikan dan menerapkan nilai Humaniora.

\section{Biaya}

Carter dan Usry (2006) mengungkapkan akuntansi biaya adalah perhitungan biaya dengan tujuan untuk aktivitas perencanaan dan pengendalian, perbaikan kualitas dan efisiensi, serta pembuatan keputusan. Mulyadi (2005) mengungkapkan bahwa biaya adalah pengorbanan sumber ekonomis yang diukur dalam satuan uang yang telah terjadi atau kemungkinan terjadi untuk mencapai tujuan tertentu.

Riwayadi (2014) mengungkapkan bahwa biaya dapat diklasifikasikan ke dalam beberapa kategori, salah satunya biaya berdasarkan mudahnya penelusuran (Traceability), yaitu :

1. Biaya langsung (direct cost) adalah biaya yang dapat secara mudah dan akurat ditelusuri ke objek biaya, yaitu biaya untuk sumber daya (resources) yang semata-mata dikonsumsi oleh objek biaya tertentu.

2. Biaya tidak langsung (indirect cost) adalah biaya yang tidak dapat secara mudah dan akurat ditelusuri ke objek biaya, yaitu biaya untuk sumber daya yang dikonsumsi secara bersama oleh beberapa objek biaya.

\section{Activity Based Costing System}

Horngren (2008) : Activity Based Costing adalah menghitung biaya setiap aktivitas serta membebankan biaya ke objek biaya seperti produk dan jasa berdasarkan aktivitas yang dibutuhkan untuk menghasilkan tiap produk dan jasa.

Garrison (2008) mengklasifikasikan aktivitas menjadi beberapa tingkatan aktivitas yang dijelaskan sebagai berikut.

\section{Unit level activity}

Yaitu aktivitas yang dilakukan untuk setiap unit produksi. Biaya yang dikeluarkan di unit level activity biasanya bersifat proporsional, maksudnya biaya yang keluar dari aktivitas tersebut sebanding dengan jumlah produk yang dihasilkan.

\section{Batch level activity}

Yaitu aktivitas yang dilakukan di unit-unit yang berhubungan dengan unit produksi tapi tidak berpengaruh dengan jumlah produk yang dihasilkan. Contohnya keamanan pabrik, pengaturan mesin produksi, dan sebagainya.

\section{Product level activity}

Yaitu aktivitas yang berkaitan dengan produk namun tidak terkait dengan unit level activity dan batch level activity. Contohnya perancangan produk, pengiklanan produk, pemasaran produk, dan sebagainya.

\section{Organization sustaining - facility level activity}

Yaitu aktivitas yang tidak berhubungan dengan ketiga aktivitas di atas. Contohnya kebersihan kantor, penyediaan jaringan komputer, penyusunan laporan dan sebagainya.

Manfaat dari Activity based costing (Hansen dan Mowen, 2009) antara lain :

1. Menyajikan biaya produk lebih akurat dan informatif.

2. Pengukuran yang lebih akurat tentang biaya yang dipicu oleh aktivitas,

3. Memudahkan memberikan informasi tentang biaya relevan untuk pengambilan keputusan. 


\section{Tarif}

Pengertian tarif tidak sama dengan harga, sekalipun keduanya menunjuk pada besarnya biaya yang harus dikeluarkan oleh konsumen. Pengertian tarif lebih terkait pada besarnya biaya yang harus dikeluarkan untuk memperoleh jasa pelayanan, sedangkan pengertian harga lebih terkait pada pengertian biaya yang harus dikeluarkan untuk memperoleh barang (Aflaj, 2001).

\section{Tarif Pelayanan BLU}

Badan Layanan Umum yang selanjutnya disingkat BLU, adalah instansi di lingkungan Pemerintah Pusat yang dibentuk untuk memberikan pelayanan kepada masyarakat berupa penyediaan barang dan/atau jasa yang dijual tanpa mengutamakan mencari keuntungan dan dalam melakukan kegiatannya didasarkan pada prinsip efisiensi dan produktivitas. BLU dapat memungut biaya kepada masyarakat sebagai imbalan atas barang/ jasa yang diberikan dalam bentuk tarif. Tarif layanan memperhitungkan seluruh biaya yang dikeluarkan oleh BLU untuk menghasilkan barang/jasa layanan. Tarif layanan tersebut disusun atas dasar perhitungan biaya per unit layanan atau hasil per investasi dana.

Penetapan tarif layanan dapat berupa:

1. tarif layanan lebih besar dari seluruh biaya yang telah dikeluarkan untuk menghasilkan barang/ jasa layanan;

2. tarif layanan sama dengan seluruh biaya yang telah dikeluarkan untuk menghasilkan barang/ jasa layanan; dan/ atau

3. tarif layanan lebih kecil dari seluruh biaya yang telah dikeluarkan untuk menghasilkan barang/ jasa layanan.

Untuk menetapkan tarif suatu layanan, perlu dilakukan perhitungan tarif layanan terlebih dahulu. Beberapa hal yang harus dipertimbangkan dalam perhitungan sekaligus penetapan tarif layanan adalah:

1. Metode dalam perhitungan biaya berisi penjelasan tentang metode-metode yang digunakan dalam perhitungan biaya per unit layanan atau hasil per investasi dana.

2. Perhitungan Biaya Berisi penjelasan perhitungan biaya per unit layanan atau hasil per investasi dana secara rinci untuk setiap layanan, termasuk langkahlangkah proses perhitungan.

\section{Tarif Badan Layanan Umum Universitas Islam Negeri Imam Bonjol Padang}

Tarif Layanan Badan Layanan Umum UIN Imam Bonjol Padang pada Kementerian Agama merupakan imbalan atas jasa layanan yang diberikan oleh Badan Layanan Umum UIN Imam Bonjol Padang pada Kementerian Agama kepada pengguna jasa. Tarif layanan tersebut terdiri dari :

1. Tarif Layanan Akademik; dan

2. Tarif Layanan Penunjang Akademik.

\section{METODE}

Penelitian ini merupakan penelitian terapan (applied research) dan menggunakan design penelitian studi deskriptif dengan pendekatan kuantitatif. Analisis perhitungan yang digunakan dalam penelitian ini adalah perhitungan unit cost yang menjadi bahagian ilmu akuntansi biaya, metode perhitungan yang digunakan adalah metode Activity Based Costing (ABC).

Data yang digunakan dalam penelitian ini adalah data sekunder. Data sekunder yang digunakan adalah data yang dicatat secara sistematis setiap periode anggaran UIN Imam Bonjol Padang berupa data anggaran dan realisasi belanja yang dapat memberikan informasi terkait biaya-biaya yang dikeluarkan untuk setiap kegiatan pelayanan. Dimana sumber data berasal dari data yang sudah ada pada bagian perencanaan dan keuangan, bagian umum, bagian akademik dan dari sumber terkait lainnya. Data yang digunakan adalah data periode anggaran tahun 2017.

Teknik pengolahan dan analisis data penelitian terdiri dari :

\section{Editing}

Semua data yang di dapat akan di koreksi terlebih dahulu, dilakukan juga cross check data di antara data yang di dapat dari para informan, dan dilakukan triangulasi data sehingga pada pengolahan data tidak terjadi kesalahan input data.

\section{Pengolahan}

Semua data dikelompokkan menurut level aktivitas dan kelompok biaya yang sudah ditentukan sebelumnya. Setelah pengelompokkan biaya dilakukan, maka dilakukan perhitungan biaya-biaya sesuai data yang ada.

3. Analisis Perhitungan Tarif

Metode analisis yang digunakan dalam penelitian ini adalah analisis deskriptif kuantitatif. Analisis deskriptif yang digunakan dalam penelitian ini untuk menggambarkan metode perhitungan unit cost untuk penetapan tarif dengan metode Activity Based Costing. Dimana tahapan perhitungan unit cost dengan metode Activity Based Costing adalah sebagai berikut.

a. Identifikasi Aktifitas

Mengidentifikasi berbagai aktifitas yang menimbulkan biaya pada pelayanan akademik mahasiswa

b. Penggolongan Berbagai Aktifitas

Klasifikasi aktivitas terdiri dari beberapa tingkatan aktivitas (level activity) yaitu unit level activity, batch level activity, product level activity dan organization sustaining level activity (Garrison dkk, 2008).

c. Identifikasi Biaya

Mengelompokkan biaya terkait biaya langsung dan biaya tidak langsung.

d. Menghitung total biaya masing-masing aktifitas layanan dan membaginya dengan Cost Driver, sehingga akan didapatkan unit cost masing-masing aktifitas. 
e. Membandingkan hasil perhitungan unit cost dengan metode activity based costing dengan tarif yang sedang berlaku.

f. Menganalisa relevansi tarif yang berlaku dengan hasil perhitungan unit cost. Jika tarif yang berlaku lebih rendah atau lebih tinggi dibandingkan dengan unit cost, maka tarif tersebut tidak relevan lagi untuk diterapkan.

\section{HASIL DAN PEMBAHASAN Klasifikasi Aktivitas}

Proses perhitungan jumlah biaya layanan BLU dengan metode Activity Based Costing ini diawali dengan mengidentifikasi berbagai aktivitas pelayanan akademik pada unit Pascasarjana UIN Imam Bonjol Padang. Aktivitas pelayanan akademik tersebut meliputi:

a. Seleksi ujian masuk Program Magister (S2)

b. Seleksi ujian masuk Program Doktor (S3)

c. Pembinaan Pendidikan Program Magister (S2)

d. Pembinaan Pendidikan Program Doktor (S3)

e. Ujian Tesis

f. Ujian Disertasi Tertutup

g. Ujian Disertasi Terbuka

h. Wisuda

Dari berbagai jenis aktivitas pelayanan UIN Imam Bonjol Padang tersebut, ditemukan beberapa aktivitas terkait aktivitas pelayanan yang diklasifikasikan ke dalam level aktivitas.

\section{Penetapan Cost Pool dan Cost Driver}

Pada tahap ini, dilakukan identifikasi biaya-biaya pada masing-masing kegiatan pelayanan. Biaya-biaya di atas diklasifikasikan ke dalam setiap kegiatan pelayanan dan diidentifikasi masing-masing Cost Drivernya beserta satuannya. Biaya-biaya tersebut terdiri dari biaya langsung dan tidak langsung. Kemudian semua biaya dikelompokkan berdasarkan tingkatan aktivitas (level activity) yaitu unit level activity, batch level activity, product level activity dan facility level activity.

Selanjutnya, pada tahap ini juga ditetapkan Cost Driver atau hal-hal yang mengakibatkan munculnya biaya. Biaya timbul berdasarkan banyak driver. Seperti pada kegiatan seleksi ujian masuk Program Magister (S2), terdapat biaya aktifitas penyusunan /pembuat bahan ujian. Pada aktifitas ini banyak drivernya ditentukan oleh jumlah naskah soal yang dipengaruhi oleh seberapa banyak mata ujian, bidang/prodi, dan berapa gelombang kegiatan tersebut diselenggarakan dalam satu tahun. Semua biaya-biaya tersebut dirincikan dalam tabel berikut.
Penetapan Cost Pool dan Cost Driver Aktivitas Seleksi Ujian Masuk Program Magister (S2)

Tabel 5. Penetapan Cost Pool dan Cost Driver aktivitas seleksi ujian masuk Program Magister (S2)

\begin{tabular}{|c|c|c|c|c|}
\hline \multirow{2}{*}{ Aktivitas } & \multirow{2}{*}{ Uraian } & \multicolumn{3}{|c|}{ Cost Driver } \\
\hline & & Banyak Driver & Satuan & Harga Per Unit \\
\hline \multicolumn{5}{|l|}{ 1. Unit level activity cost } \\
\hline Penyusunan/Pembuat bahan ujan & $2 \mathrm{MU} \times 4 \mathrm{BD} \times 2 \mathrm{gel}$ & 16 & Naskah Soal & 250.000 \\
\hline Telaah Hasil Ujian & 100 org $\times 2 \mathrm{MU} \times 2$ gel & 400 & ORG & 50.000 \\
\hline Penguji Lisan & 100 org $\times 2$ gel & 200 & ORG & 25.000 \\
\hline Pengawas Ujän & 10 lokal $\times 2$ org $\times \times 3$ hr $\times 2$ gel & 120 & $\mathrm{OH}$ & 300.000 \\
\hline \multicolumn{5}{|l|}{ 2. Batch level actwity cost } \\
\hline \multicolumn{5}{|l|}{ Honor panitia ujian masuk Program } \\
\hline \multicolumn{5}{|l|}{ Pascasarjana } \\
\hline - Penanggung jawab & 1 org $\times 2$ gel & 2 & ORG & 300.000 \\
\hline - Ketua & 1 org $x 2$ gel & 2 & ORG & 266.667 \\
\hline - Wakil Ketua & 1 org $x 2$ gel & 2 & ORG & 266.667 \\
\hline - Sekretaris & 1 org $x 2$ gel & 2 & ORG & 200.000 \\
\hline - Anggota & $12 \operatorname{org} x 2$ gel & 24 & ORG & 200.000 \\
\hline 3. Product level activity cost & - & - & - & - \\
\hline \multicolumn{5}{|l|}{ 4. Facility level activity cost } \\
\hline - Gaji pegawai ASN & $3 \mathrm{hr} \times 2$ gel & 6 & hrithn & 180.024 .698 \\
\hline - Honor pegawai BLU & $3 \mathrm{hr} \times 2 \mathrm{gel}$ & 6 & hrithin & 24.700 .000 \\
\hline - Honor pegawai $\mathrm{K} 3$ & $3 \mathrm{hr} \times 2$ gel & 6 & hrithin & 24.700 .000 \\
\hline - Honor satpam & $3 \ln \times 2$ gel & 6 & hir/thn & 34.233 .333 \\
\hline - Pemakaian listrik & $3 \mathrm{hr} \times 2 \mathrm{gel}$ & 6 & hir/thn & 56.836 .800 \\
\hline - Pemeliharaan gedung & $3 \mathrm{hr} \times 2$ gel & 6 & hir/thin & 272.201 .056 \\
\hline - Penyusutan gedung & 3 hr $\times 2$ gel & 6 & hir/thin & 455.357 .782 \\
\hline
\end{tabular}

Penetapan Cost Pool dan Cost Driver Aktivitas Seleksi ujian masuk Program Doktor (S3)

Tabel 6. Penetapan Cost Pool dan Cost Driver aktivitas seleksi ujian masuk Program Doktor (S3)

\begin{tabular}{|c|c|c|c|c|}
\hline \multirow{2}{*}{ Aktivitas } & \multirow{2}{*}{ Rincian } & \multicolumn{3}{|c|}{ Cost Diviver } \\
\hline & & Banyak Diver & Satuan & Harga Per Unit \\
\hline \multicolumn{5}{|l|}{ 1. Unit level activity cost } \\
\hline Penyusunan/Pembuat bahan ujian & $3 \mathrm{MU} \times 2 \mathrm{BD} \times 2 \mathrm{Gel}$ & 12 & Naskah Soal & 280.000 \\
\hline Telaah Hasil Ujian & 50 org $x 3 \mathrm{MU} \times 2$ gel & 300 & Orang & 75.000 \\
\hline Penguji Lisan & 50 org $\times 2 \times 2$ gel & 200 & Orang & 50.000 \\
\hline Pengawas Ujian & $6 \mathbb{k l} \times 2$ org $x 3$ hr $x 2$ gel & 72 & $\mathrm{OH}$ & 300.000 \\
\hline \multicolumn{5}{|l|}{ 2. Batch level activity cost } \\
\hline \multicolumn{5}{|l|}{ Honor panitia ujian masuk } \\
\hline \multicolumn{5}{|l|}{ Program Pascasarjana } \\
\hline - Penanggung jawab & 1 org $x 2$ gel & 2 & ORG & 150.000 \\
\hline - Ketua & 1 org $x 2$ gel & 2 & ORG & 133.333 \\
\hline - Wakil Ketua & 1 org $x 2$ gel & 2 & ORG & 133.333 \\
\hline - Sekretaris & 1 org $x 2$ gel & 2 & ORG & 100.000 \\
\hline - Anggota & 12 org $x 2$ gel & 24 & ORG & 100.000 \\
\hline 3. Product level activity cost & $\cdot$ & $\cdot$ & $\cdot$ & $\cdot$ \\
\hline \multicolumn{5}{|l|}{ 4. Facility level activity cost } \\
\hline - Gaji pegawai ASN & $3 \mathrm{hr} \times 2$ gel & 6 & hr/thn & 34.971 .685 \\
\hline - Honor pegawai BLU & 3 hr $x 2$ gel & 6 & hr/thn & 24.700 .000 \\
\hline - Honor pegawai $\mathrm{K} 3$ & 3 hr $\times 2$ gel & 6 & hr/thn & 24.700 .000 \\
\hline - Honor satpam & $3 \mathrm{hr} \times 2$ gel & 6 & $\mathrm{hr} / \mathrm{thn}$ & 34.233 .333 \\
\hline - Pemakaian listrik & $3 \mathrm{hr} \times 2$ gel & 6 & hr/thn & 56.836 .800 \\
\hline - Pemeliharaan gedung & $3 \mathrm{hr} \times 2$ gel & 6 & hr/thn & 272.201 .056 \\
\hline - Penyusutan gedung & $3 \mathrm{hr} \times 2$ gel & 6 & hr/thn & 455.357 .782 \\
\hline
\end{tabular}


Ramayani Eka Putri et al, Evaluasi Tarif Pelayanan Badan Layanan Umum dengan Metode Unit Cost Pada Universitas Islam Negeri Imam Bonjol Padang

\section{Penetapan Cost Pool dan Cost Driver Aktivitas Pembinaan Pendidikan Program Magister (S2)}

Tabel 7. Penetapan Cost Pool dan Cost Driver aktivitas pembinaan pendidikan Program Magister (S2)

\begin{tabular}{|c|c|c|c|c|}
\hline \multirow{2}{*}{ Aktivitas } & \multirow{2}{*}{ Rincian } & \multicolumn{3}{|c|}{ Cost Driver } \\
\hline & & Banyak Driver & Satuan & Harga Per Unit \\
\hline \multicolumn{5}{|l|}{ 1. Unit level activity cost } \\
\hline \multicolumn{5}{|l|}{ Honor kelebihan jam mengajar } \\
\hline - Guru besar & 31 Org $x 16$ TMK $\times 2$ SMT & 992 & TMK & 300.000 \\
\hline - Doktor & 87 Org $\times 16$ TMK $\times 2$ SMT & 2784 & TMK & 250.000 \\
\hline \multicolumn{5}{|l|}{ Honor Mengajar } \\
\hline - Guru besar & 2 Org $\times 16$ TMK $\times 2$ SMT & 64 & TMK & 300.000 \\
\hline - Doktor & 1 Org $\times 16$ TMK $\times 2$ SMT & 32 & TMK & 250.000 \\
\hline \multicolumn{5}{|l|}{ Honor Pembimbing Tesis } \\
\hline - Guru besar & 2 Org $\times 30$ MHS $\times 2$ SMT & 120 & ORG & 500.000 \\
\hline - Doktor & 2 Org $x 60$ MHS $\times 2$ SMT & 240 & ORG & 400.000 \\
\hline \multicolumn{5}{|l|}{ Honor pelaksana ujian semester } \\
\hline - Pembuat soal program magister S2 & $75 \mathrm{mk} \times 2 \mathrm{smt}$ & 150 & MK & 250.000 \\
\hline - Pemeriksa ujian Semester program S2 & 453 org $\times 6 \mathrm{mk} \times 2 \mathrm{smt}$ & 3600 & ORG & 15.000 \\
\hline - Pengawas ujian semester & 23 Org $\times 6$ hr x 2 smt & 276 & LKL & 300.000 \\
\hline \multicolumn{5}{|l|}{ Ujian Proposal Tesis } \\
\hline - Ketua & 100 mhs $x 1$ org $x 2 \mathrm{smt}$ & 200 & MHS & 100.000 \\
\hline - Sekretaris & $100 \mathrm{mhs} \times 1$ org $x 2 \mathrm{smt}$ & 200 & MHS & 100.000 \\
\hline - Penguji & 100 mhs $\times 2$ org $\times 2$ smt & 400 & MHS & 100.000 \\
\hline \multirow{2}{*}{\multicolumn{5}{|c|}{ 2. Batch level activity cost }} \\
\hline Belanja perjalanan Dosen Tamu PBM S2 \& S3 & & & & \\
\hline - Tiket PP Dosen S2 dan S3 Luar Propinsi & $16 \operatorname{org} x 3 \mathrm{Keg}$ & 48 & Keg & $3.000 .000^{*}$ \\
\hline - Akomondasi & 16 org $\times 3 \operatorname{Keg} \times 1$ hr & 48 & $\mathrm{OH}$ & $450.000^{*}$ \\
\hline \multicolumn{5}{|l|}{ Honor Dewan Pertimb angan Akademik (DPA) } \\
\hline - Penanggung Jawab & $1 \operatorname{org} \times 2 \mathrm{SMT}$ & 2 & kgt & $400.000 *$ \\
\hline - Ketua & 1 org $\times 2$ SMT & 2 & kgt & $350.000 *$ \\
\hline - Sekretaris/Anggota & 13 org $x 2$ SMT & 26 & kgt & $300.000^{*}$ \\
\hline Honor penasehat akademik (PA) & 453 ORG & 453 & ORG & 35.000 \\
\hline 3. Product level activity cost & - & - & - & - \\
\hline \multicolumn{5}{|l|}{ 4. Facility level activity cost } \\
\hline - Gaji pegawai ASN & $120 \mathrm{hr} \times 2 \mathrm{sem}$ & 240 & hrthn & 180.024 .698 \\
\hline - Honor pegawai BLU & $120 \mathrm{hr} \times 2 \mathrm{sem}$ & 240 & $\mathrm{hr} / \mathrm{thn}$ & 24.700 .000 \\
\hline - Honor pegawai K3 & $120 \mathrm{hr} \times 2 \mathrm{sem}$ & 240 & hrthn & 24.700 .000 \\
\hline - Honor satpam & $120 \mathrm{hr} \times 2 \mathrm{sem}$ & 240 & hrt thn & 34.233 .333 \\
\hline - Pemakaian listrik & $120 \mathrm{hr} \times 2 \mathrm{sem}$ & 240 & hrthn & 56.836 .800 \\
\hline - Pemeliharaan gedung & $120 \mathrm{hr} \times 2 \mathrm{sem}$ & 240 & hrthn & 272.201 .056 \\
\hline - Penyusutan gedung & $120 \mathrm{hr} \times 2 \mathrm{sem}$ & 240 & hr/thn & 455.357 .782 \\
\hline
\end{tabular}

\section{Penetapan Cost Pool dan Cost Driver Aktivitas Pembinaan Pendidikan Program Doktor (S3)}

Tabel 8. Penetapan Cost Pool dan Cost Driver aktivitas pembinaan pendidikan Program Doktor (S3)

\begin{tabular}{|c|c|c|c|c|}
\hline \multirow{2}{*}{ Aktivitas } & \multirow{2}{*}{ Rincian } & \multicolumn{3}{|c|}{ Cost Driver } \\
\hline & & Banyak Dive 1 & Satuan & Harga Per Uni \\
\hline \multicolumn{5}{|l|}{ 1. Unit level activity cost } \\
\hline \multicolumn{5}{|l|}{ Honor kelebihan jam mengajar } \\
\hline - Guru besar & 7 Org $x 16$ TMK x 2 SMT & 224 & TMK & 400.000 \\
\hline \multicolumn{5}{|l|}{ Honor Mengajar } \\
\hline - Guru besar & 8 Org $\mathrm{x} 16 \mathrm{TMK} \times 2$ & 256 & TMK & 400.000 \\
\hline \multicolumn{5}{|l|}{ Honor Pembimbing Disertasi } \\
\hline - Guru besar & 2 Org $\times 20$ MHS $\times 2$ SMT & 80 & org & 1.000 .000 \\
\hline - Doktor & 2 Org $\times 5$ MHS $\times 2$ SMT & 20 & org & 850.000 \\
\hline \multicolumn{5}{|l|}{ Honor pelaksana ujian semester } \\
\hline - Pembuat soal program doktor S3 & $20 \mathrm{mk} \times 2 \mathrm{smt}$ & 40 & $\mathrm{mk}$ & 280.000 \\
\hline - Pemeriksa ujian Semester doktor S3 & 40 org $\times 6 \mathrm{mk} \times 2 \mathrm{smt}$ & 480 & org & 20.000 \\
\hline - Pengawas ujian semester & $(2$ Org $\times 6 \mathrm{hr} \times 2 \mathrm{smt}$ & 144 & $\mathbb{k} 1$ & 300.000 \\
\hline \multicolumn{5}{|l|}{ Ujian Proposal Disertasi } \\
\hline - Ketua & $30 \mathrm{mhs} x 1$ org $x 2 \mathrm{smt}$ & 60 & mhs & 170.000 \\
\hline - Sekretaris & 30 mhs $x 1$ org $x 2$ smt & 60 & mhs & 170.000 \\
\hline - Penguji & $30 \mathrm{mhs} \times 3$ org $x 2 \mathrm{smt}$ & 180 & mhs & 200.000 \\
\hline \multicolumn{5}{|l|}{ 2. Batch level activity cost } \\
\hline \multicolumn{5}{|l|}{ Beanja perjalanan Dosen Tamu PBM S2 \& S3 } \\
\hline - Tiket PP Dosen S2 dan S3 Luar Propinsi & 16 org $x 3 \mathrm{Keg} \times 1 \mathrm{hr}$ & 48 & Keg & $3.000 .000 *$ \\
\hline - Akomondasi & 16 org $x 3 \mathrm{Keg} \times 1 \mathrm{hr}$ & 48 & $\mathrm{OH}$ & $450.000^{*}$ \\
\hline \multicolumn{5}{|l|}{ Honor Dewan Pertimbangan Akademik (DPA) } \\
\hline - Penanggung Jawab & 1 org $\times 2$ SMT & 2 & $\mathrm{kgt}$ & $400.000 *$ \\
\hline - Ketua & 1 org $\times 2$ SMT & 2 & kgt & $350.000 *$ \\
\hline - Sekretaris/Anggota & 13 org $x 2$ SMT & 26 & kgt & $300.000 *$ \\
\hline Honor penasehat akademik (PA) & 118 ORG & 118 & ORG & 35.000 \\
\hline \multicolumn{5}{|l|}{ 3. Product level activity cost } \\
\hline \multicolumn{5}{|l|}{ 4. Facility level activity cost } \\
\hline - GajipegawaiASN & $120 \mathrm{hr} \times 2 \mathrm{sem}$ & 240 & hrothn & 180.024 .698 \\
\hline - Honor pegawai BLU & $120 \mathrm{hr} \times 2 \mathrm{sem}$ & 240 & hrothn & 24.700 .000 \\
\hline - Honor pegawai K3 & $120 \mathrm{hr} \times 2 \mathrm{sem}$ & 240 & hrothn & 24.700 .000 \\
\hline - Honor satpam & $120 \mathrm{hr} \times 2 \mathrm{sem}$ & 240 & hrothn & 34.233 .333 \\
\hline - Pemakaian listrik & $120 \mathrm{hr} \times 2 \mathrm{sem}$ & 240 & $\mathrm{hr} / \mathrm{thn}$ & 56.836 .800 \\
\hline - Pemelharaan gedung & $120 \mathrm{hr} \times 2 \mathrm{sem}$ & 240 & $\mathrm{hr} / \mathrm{thn}$ & 272.201 .056 \\
\hline - Penyusutan gedung & $120 \mathrm{hr} \times 2 \mathrm{sem}$ & 240 & hrthn & 455.357 .782 \\
\hline
\end{tabular}

Penetapan Cost Pool dan Cost Driver Aktivitas Ujian Tesis

Tabel 9. Penetapan Cost Pool dan Cost Driver aktivitas ujian tesis

\begin{tabular}{|c|c|c|c|c|}
\hline \multirow{2}{*}{ Aktivitas } & \multirow{2}{*}{ Rincian } & \multicolumn{3}{|c|}{ Cost Driver } \\
\hline & & Banyak Driver & Satuan & Harga Per Unit \\
\hline \multicolumn{5}{|l|}{ 1. Unit level activity cost } \\
\hline \multicolumn{5}{|l|}{ Honor pengujiujujian tesis } \\
\hline - Pengujil/Ketta & 1 org $x 80$ mhs $\times 2$ smt & 160 & mhs & 200.000 \\
\hline - PengujiII/Sekretar's & $101 \mathrm{~g} X 80 \mathrm{mhs} \times 2 \mathrm{smt}$ & 160 & mhs & 150.000 \\
\hline - PengujjIII,IV & $201 \mathrm{~g} \times 80$ Mhs $\times 2$ smt & 320 & mhs & 250.000 \\
\hline - Penguji V,VI & $201 \mathrm{~g} \times 80$ Mhs $\times 2$ smt & 320 & mhs & 200.000 \\
\hline 2. Batch level activity cost & $\cdot$ & $\cdot$ & $\cdot$ & - \\
\hline 3. Product level activity cost & - & - & - & $\cdot$ \\
\hline \multicolumn{5}{|l|}{ 4. Facility level activity cost } \\
\hline - GajipegawaiASN & 32 hr $\times 2$ gel & 64 & hrothin & 180.024 .698 \\
\hline - Honor pegawai BLU & 32 hrr $\times 2$ gel & 64 & hirthin & 24.700 .000 \\
\hline - Honor pegawaiK3 & 32 hrr $\times 2$ gel & 64 & hrothin & 24.700 .000 \\
\hline - Honor satpall & 32 hrr $\times 2$ gel & 64 & hrothin & 34.233 .333 \\
\hline - Pemakaian listrik & 32 hr $\times 2$ gel & 64 & hrothin & 56.836 .800 \\
\hline - Pemeliharaan gedung & 32 hr $\times 2$ gel & 64 & hirthin & 272.201 .056 \\
\hline - Penylsistan gedung & $32 \mathrm{hr} \times 2 \mathrm{gel}$ & 64 & hrothin & 455.357 .782 \\
\hline
\end{tabular}

Penetapan Cost Pool dan Cost Driver Aktivitas Ujian Disertasi Tertutup

Tabel 10. Penetapan Cost Pool dan Cost Driver aktivitas ujian disertasi tertutup

\begin{tabular}{|c|c|c|c|c|}
\hline \multirow{2}{*}{ Aktivitas } & \multirow{2}{*}{ Rincian } & \multicolumn{3}{|c|}{ Cost Driver } \\
\hline & & Banyak D liver & Satuan & Harga Per Unit \\
\hline \multicolumn{5}{|l|}{ 1. Unit level activity cost } \\
\hline \multicolumn{5}{|l|}{ Honor penguji uijan } \\
\hline - Pengujil/Ketua & 15 mhs $\times 2$ smt & 30 & mhls & 500.000 \\
\hline - PengujiII/Sekretaris & $15 \mathrm{mhs} \times 2 \mathrm{smt}$ & 30 & mhs & 500.000 \\
\hline - PengujiIII, IV & $15 \mathrm{mhs} \times 3$ org $\times 2 \mathrm{smt}$ & 90 & mhs & 500.000 \\
\hline - PengujiV, VI & $15 \mathrm{mhs} \times 2$ org $\times 2 \mathrm{smt}$ & 60 & mhs & 500.000 \\
\hline 2. Batch level activity cost & $\cdot$ & - & $\cdot$ & - \\
\hline 3. Product level activity cost & $\cdot$ & $\cdot$ & $\cdot$ & $\cdot$ \\
\hline \multicolumn{5}{|l|}{ 4. Facility level activity cost } \\
\hline - GajipegawaiASN & 15 hr $\times 2$ gel & 30 & hrrthn & 34.971 .685 \\
\hline - Honor pegawaiBLU & 15 hr $\times 2$ gel & 30 & hrithn & 24.700 .000 \\
\hline - Honor pegawaiK3 & 15 hr $\times 2$ gel & 30 & hrithn & 24.700 .000 \\
\hline - Honor satpam & 15 hr $\times 2$ gel & 30 & hrrthn & 34.233 .333 \\
\hline - Pemakaian listrik & 15 hr $\times 2$ gel & 30 & hrethn & 56.836 .800 \\
\hline - Pemelilaraan gedung & 15 hr $\times 2$ gel & 30 & hrethn & 272.201 .056 \\
\hline - Penyusutan gedung & 15 hr $\times 2$ gel & 30 & hrethn & 455.357 .782 \\
\hline
\end{tabular}


Ramayani Eka Putri et al, Evaluasi Tarif Pelayanan Badan Layanan Umum dengan Metode Unit Cost Pada Universitas Islam Negeri Imam Bonjol Padang

Penetapan Cost Pool dan Cost Driver Aktivitas Ujian Disertasi Terbuka

Tabel 11. Penetapan Cost Pool dan Cost Driver aktivitas ujian disertasi terbuka

\begin{tabular}{|c|c|c|c|c|}
\hline \multirow{2}{*}{ Aktivitas } & \multirow{2}{*}{ Rincian } & \multicolumn{3}{|c|}{ Cost Driver } \\
\hline & & Banyak Driver & Satuan & Harga Per Unit \\
\hline \multicolumn{5}{|l|}{ 1. Unit level activity cost } \\
\hline - Undangan & 20 mhs $\times 100 \mathrm{lbr} \times 2 \mathrm{smt}$ & 4000 & br & 7.500 \\
\hline - Spanduk & 20 mhs $\times 2$ smt $\times 1$ bh & 40 & bh & 300.000 \\
\hline - Konsumsi sneck & 20 mhs $\times 100$ org $\times 2 \mathrm{smt}$ & 4000 & org & 10.000 \\
\hline - Konsumsi makan & 20 mhs $x 25$ org $x 2 \mathrm{smt}$ & 1000 & org & 20.000 \\
\hline \multicolumn{5}{|l|}{ Honor penguji ujian } \\
\hline - PengujiI & $20 \mathrm{mhs} \times 2 \mathrm{smt}$ & 40 & mhs & 500.000 \\
\hline - Penguji II & $20 \mathrm{mhs} \times 2 \mathrm{smt}$ & 40 & mhs & 500.000 \\
\hline - $\quad$ Penguji III, IV, V & $20 \mathrm{mhs} \times 3$ org $\times 2 \mathrm{smt}$ & 120 & mhs & 500.000 \\
\hline - Penguji VI, VII & $20 \mathrm{mhs} \times 2$ org $\times 2 \mathrm{smt}$ & 80 & mhs & 500.000 \\
\hline 2. Batch level activity cost & - & - & - & - \\
\hline 3. Product level activity cost & - & - & - & - \\
\hline \multicolumn{5}{|l|}{ 4. Facility level activity cost } \\
\hline - GajipegawaiASN & $20 \mathrm{hr} \times 2$ gel & 40 & hir/thn & 34.971 .685 \\
\hline - Honor pegawai BLU & $20 \mathrm{hr} \times 2 \mathrm{gel}$ & 40 & hrr thn & 24.700 .000 \\
\hline - Honor pegawai $\mathrm{K} 3$ & $20 \mathrm{hr} \times 2 \mathrm{gel}$ & 40 & hrrthn & 24.700 .000 \\
\hline - Honor satpam & $20 \mathrm{hr} \times 2 \mathrm{gel}$ & 40 & hrr thn & 34.233 .333 \\
\hline - Pemakainn listrik & $20 \mathrm{hr} \times 2 \mathrm{gel}$ & 40 & hrrthn & 56.836 .800 \\
\hline - Pemeliharaan gedung & $20 \mathrm{hr} \times 2 \mathrm{gel}$ & 40 & hrrothn & 272.201 .056 \\
\hline - Penyusutan gedung & $20 \mathrm{hr} \times 2$ gel & 40 & hir/thn & 455.357 .782 \\
\hline
\end{tabular}

\section{Penetapan Cost Pool dan Cost Driver Aktivitas Wisuda}

Tabel 12. Penetapan Cost Pool dan Cost Driver aktivitas

\begin{tabular}{|c|c|c|c|c|}
\hline \multirow{3}{*}{ Aktivitas } & \multicolumn{4}{|l|}{ wisuda } \\
\hline & \multirow{2}{*}{ Rincian } & \multicolumn{3}{|c|}{ Cost Diver } \\
\hline & & Banyak Driver & Satuan & Harga PerUnit \\
\hline \multicolumn{5}{|l|}{ 1. Unit level activity cost } \\
\hline - Snack rapatpersiapan & $80 \mathrm{ORG} \times 5 \mathrm{HR} \times 2$ & 800 & $\mathrm{OK}$ & 15.000 \\
\hline - Foto Wisudawan & 850 org $x 2 \mathrm{keg}$ & 1700 & ok & 50.000 \\
\hline - Cetak buku wisuda & 900 ORG $\times 2$ KEG & 1800 & ok & 50.000 \\
\hline - Cetak map ijazah & 850 org $\times 2 \mathrm{KEG}$ & 1700 & ok & 50.000 \\
\hline - Cetak undangan & 1500 LBR $\times 2 \mathrm{KEG}$ & 3000 & ok & 6.000 \\
\hline - konsumsi wisudawan & 850 org $\times 2$ kotak $\times 2$ keg & 3400 & ok & 25.000 \\
\hline - Makan Senat 2 protein & 47 org $x 2 \mathrm{keg}$ & 94 & ok & 30.000 \\
\hline - snack senat & 47 org $x 2 \mathrm{keg}$ & 94 & ok & 15.000 \\
\hline - Makan panitia & 80 org $\times 1$ kalix $2 \mathrm{keg}$ & 160 & ok & 25.000 \\
\hline - Makan Petugas Keamanan Humas dan K3 & 150 org $x 2 \mathrm{keg}$ & 300 & $\mathrm{OK}$ & 25.000 \\
\hline - Makan dosen/karyawan dan tamı & 550 org $x 2 \mathrm{keg}$ & 1100 & ok & 25.000 \\
\hline - Makan wisudawan pada gladibersih & 850 org $x 2 \mathrm{keg}$ & 1700 & ok & 25.000 \\
\hline - makan paduan suara & $60 \operatorname{org} x 2 \mathrm{keg}$ & 120 & ok & 25.000 \\
\hline \multicolumn{5}{|l|}{ 2. Batch level activity cost } \\
\hline - Buku wisudawan terbaik & $10 \times 2 \mathrm{Keg}$ & 20 & $\mathrm{OBH}$ & 100.000 \\
\hline - cetak piagam terbaik dan aktivis kampus & $15 \times 2 \mathrm{keg}$ & 30 & $\mathrm{OBH}$ & 10.000 \\
\hline \multicolumn{5}{|l|}{ Honor output kegiatan wisuda } \\
\hline - Penanggung Jawab & 1 org $x 2 \mathrm{Keg}$ & 2 & ok & 450000 \\
\hline - Ketua & 1 org $x 2 \mathrm{keg}$ & 2 & ok & 400000 \\
\hline - Sekretaris & 1 org $x 2 \mathrm{keg}$ & 2 & ok & 300000 \\
\hline - Anggota & 77 org $x 2 \mathrm{keg}$ & 154 & ok & 300000 \\
\hline \multicolumn{5}{|l|}{ 3. Product level activity cost } \\
\hline - Spanduk [7 bh) & $7 \mathrm{bh}$ & 7 & $\mathrm{BH}$ & 300.000 \\
\hline - Dokumentasi dan publikasi $2 \mathrm{KEG}$ & $2 \mathrm{KEG}$ & 2 & KEG & 12.000 .000 \\
\hline - Dekorasi Wisuda & $2 \mathrm{KEG}$ & 2 & KEG & 5.000 .000 \\
\hline
\end{tabular}

\begin{tabular}{lllll} 
4. Facility level activity cost & & & & \\
- Pemeliharaan gedung & $2 \mathrm{hr} \times 2 \mathrm{keg}$ & 4 & $\mathrm{hr}$ thn & 292.292 .336 \\
- Penyusutan gedung & $2 \mathrm{hr} \times 2 \mathrm{keg}$ & 4 & $\mathrm{hr}$ thn & 207.473 .690 \\
- Pemakaian listrik & $2 \mathrm{hr} \times 2 \mathrm{keg}$ & 4 & $\mathrm{hr}$ thn & 479.357 .175 \\
\hline
\end{tabular}

\section{Perhitungan Unit Cost}

Setelah biaya-biaya sudah teridentifikasi, unit cost per output kegiatan dapat dihitung dengan membagi total biaya tiap aktifitas dengan cost driver. Karena tarif akan dibebankan kepada mahasiswa, maka cost driver yang akan digunakan untuk menghitung unit cost masing- masing jenis layanan adalah mahasiswa dengan rumus sebagai berikut:

Unit Cost $=\frac{\text { Total biaya tiap aktivitas }}{\text { Cost Driver }}$

Sumber : Daljono (2005)

Dari hasil perhitungan unit cost tersebut maka didapatlah gambaran terkait tarif pelayanan BLU UIN Imam Bonjol Padang. Tabel 1 menunjukkan hasil perhitungan unit cost per output kegiatan dengan metode $A B C$ serta perbandingannya dengan tarif yang sedang berlaku.

Tabel 13. Hasil perhitungan unit cost per output kegiatan dengan metode $A B C$ serta perbandingannya dengan tarif lama

\begin{tabular}{llrrr}
\hline No. & \multicolumn{1}{c}{ Kegiatan } & Tarif & Perhitungan & \multirow{2}{*}{ Keter angan } \\
& & \multicolumn{1}{c}{ Berlaku } & \multicolumn{1}{c}{ ABC } & \\
\hline 1 & Seleksi Ujian Masuk Program Magister (S2) & 250.000 & 918.389 & Underrated \\
2 & Seleksi Ujian Masuk Program Doktor (S3) & 350.000 & 1.617 .312 & Underrated \\
& Sumbangan Pembinaan Pendidikan (SPP) & 4.000 .000 & 2.632 .010 & Overrated \\
& $\begin{array}{l}\text { Program Magister (S2) } \\
\text { Sumbangan Pembinaan Pendidikan (SPP) }\end{array}$ & 6.000 .000 & 5.272 .139 & Overrated \\
& ProgramDoktor (S3) & 1.800 .000 & 2.581 .483 & Underrated \\
5 & Ujian Tesis & 6.000 .000 & 6.828 .707 & Underrated \\
6 & Ujian Disertasi Tertutup (Pendahuluan) & 10.000 .000 & 9.378 .707 & Overrated \\
7 & Biaya Ujian DisertasiTerbuka (Promosi) & 450.000 & 754.675 & Underrated \\
8 & Wisuda & & & \\
\hline & & & & \\
\hline
\end{tabular}

Perhitungan unit cost yang dilakukan terhadap aktifitas aktifitas pelayanan UIN Imam Bonjol Padang di atas telah menunjukkan bahwa tarif berlaku yang diajukan di awal peralihan status menjadi sebuah universitas tersebut, sebagian besar sudah tidak relevan lagi. Hal ini jelas terlihat ketika dibandingkan dengan tarif layanan yang berlaku. Perhitungan unit cost dengan metode $A B C$ telah memperlihatkan berapa biaya keseluruhan yang dikeluarkan untuk setiap aktifitas layanan per mahasiswa.

Adanya perhitungan biaya tidak langsung membuat jumlah biaya masing-masing aktifitas mengakibatkan selisih yang sangat signifikan. Biayabiaya tidak langsung tersebut adalah gaji pegawai ASN di unit Pascasarjana, honor pegawai BLU di unit Pascasarjana, dan biaya pemakaian listrik pada gedunggedung yang digunakan untuk menyelenggarakan aktifitas unit Pascasarjana, serta biaya penyusutan dan pemeliharaan gedung-gedung tersebut. Biaya-biaya tersebut adalah biaya-biaya yang akan tetap muncul meskipun aktifitas-aktifitas dan atau salah satu aktifitas di unit Pascasarjana tidak terselenggara. Namun biayabiaya tersebut sudah semestinya diperhitungkan karena tanpa adanya biaya-biaya tersebut, aktifitas tidak akan terselenggara. Misalnya, jika tidak ada pegawai ASN dan BLU, maka pelayanan kampus tidak akan terselenggara dengan baik. Karena pada dasarnya universitas adalah instansi yang melayani masyarakat/ mahasiswa dalam bidang pendidikan. Untuk itu instansi perlu mengeluarkan biaya untuk gaji dan honor para 
pegawainya untuk menyediakan pelayanan terbaik sesuai dengan kebutuhan mahasiswa, termasuk dalam pelayanan dalam suatu aktifitas mahasiswa. Begitu juga dengan biaya pemakaian listrik, penyusutan dan pemeliharaan gedung. Tanpa adanya fasilitas listrik dan gedung, aktifitas-aktifitas mahasiswa tidak akan terselenggara dengan baik. Karena itulah biaya langsung perlu ditelusuri dan diidentifikasi dalam perhitungan unit cost aktifitas layanan kampus ini.

Setelah memperhitungkan seluruh komponen biaya, hasil perhitungan unit cost metode $A B C$ ini dapat dijadikan sebagai referensi bagi UIN Imam Bonjol untuk mengevaluasi kembali tarif layanan BLUnya. Meskipun perbedaan hasil perhitungan biaya ini akan mengakibatkan kenaikan tarif yang sangat signifikan, namun penetapan tarif harus tetap mengacu kepada dasar pertimbangan dalam menetapkan tarif layanan BLU, yaitu kontinuitas dan pengembangan, daya beli masyarakat, asas keadilan dan kepatutan, dan kompetisi yang sehat.

Adanya evaluasi tarif juga sebagai upaya optimalisasi pendapatan akan dapat memperkuat kedudukan UIN Imam Bonjol sebagai salah satu lembaga pendidikan berupa BLU. Sehingga UIN Imam Bonjol dapat menjadi lebih mandiri, dan dapat mendukung jalannya reformasi keuangan negara. Selain itu status UIN Imam Bonjol Padang sebagai salah satu Universitas Islam Negeri juga akan semakin kuat dan berkembang, meningkatkan kualitas pelayanan dan mutu pendidikan sehingga akan menciptakan lulusan-lulusan terbaik yang dapat mencerdaskan bangsa.

\section{SIMPULAN}

Tarif kegiatan pelayanan program Pasca Sarjana UIN Imam Bonjol Padang sebagian besar masih terbilang rendah (underrated) karena lebih rendah dari pada unit cost untuk menyelenggarakan kegiatan layanannya.

Kegiatan-kegiatan yang memiliki tarif lebih rendah (underrated) dari biayanya antara lain: seleksi ujian masuk program magister (S2); seleksi ujian masuk program doktor (S3); ujian tesis; ujian disertasi tertutup; dan wisuda.

Meskipun belum memperhitungkan biaya-biaya tidak langsung, tarif yang dikenakan pada mahasiswa untuk kegiatan aktifitas tersebut sudah lebih dari $100 \%$ untuk menutupi biaya-biaya yang sudah dikeluarkan. Hal ini dapat terjadi karena adanya perbedaan data dimana pada tarif sebelumnya menggunakan data asumsi 2014 sedangkan perhitungan $A B C$ dalam penelitian ini menggunakan data anggaran 2017. Selain adanya perubahan-perubahan biaya, terdapat juga beberapa komponen biaya langsung yang sudah tidak dianggarkan lagi di tahun 2017. Fluktuasi jumlah mahasiswa yang mengikuti kegiatan juga sangat berpengaruh.

Dengan adanya perhitungan unit cost per output kegiatan dan seiring dengan perkembangan UIN Imam
Bonjol Padang saat ini, maka tarif yang berlaku sekarang sudah tidak relevan lagi dan perlu dilakukan evaluasi tarif untuk mengoptimalkan pendapatan BLU UIN Imam Bonjol Padang sebagai salah satu strategi manajemen keuangan. Selain menaikan tarif pelayanan, pengembangan pada sektor layanan lain baik layanan pendidikan ataupun non-pendidikan juga dapat menjadi alternatif untuk meningkatkan penerimaan BLU.

\section{DAFTAR PUSTAKA}

Aflaj, Ruhul. 2001. Pemikiran "Public and Private Mix" dalam Pelayanan Kesehatan Dasar. Semiloka Public - Private Mix dalam Pelayanan Kesehatan. Jakarta.

Carter, Wiliam K dan Milton F. Usry, 2006. Akuntansi Biaya, Edisi Ketigabelas, Buku I. Jakarta: Salemba Empat.

Daljono. 2005. Akuntansi Biaya. Edisi dua,Semarang: Badan penerbit Universitas Diponegoro.

Departemen Dalam Negeri (Pengembangan Pelayanan Terpadu Satu Pintu, 2004).

Fontanella, Amy, Sukartini, Novrina Chandra. 2015. Tesis Implementasi Perhitungan Biaya Satuan (Unit cost) Penyelenggaraan Pendidikan Dengan Pendekatan Activity Based Costing (ABC):Peluang Dan Tantangan (Studi Pada Politeknik Negeri Padang).

Garrison, R. H., Noreen, E. W. Dan Brewer, P. C. 2008. Manajerial Accounting. Jakarta: Salemba Empat.

Hansen dan Mowen. 2009. Akuntansi Manajerial, Buku 1 Edisi 8. Jakarta: Salemba Empat.

Horngren, dkk. 2008. Akuntansi Biaya. Jakarta: Penerbit Erlangga.

Peraturan Menteri Pendidikan dan Kebudayaan Nomor 93 Tahun 2014 tentang Tata Cara Penetapan Standar Satuan Biaya Operasional Perguruan Tinggi Negeri Badan Hukum.

Keputusan Menteri Pendayagunaan Aparatur Negara Nomor 63 Tahun 2003. Tentang Pedoman Pelayanan Publik.

Keputusan Menteri Keuangan Nomor 386/KMK.05/2015. Tentang Penetapan Institut Agama Islam Negeri Imam Bonjol Padang Pada Kementerian Agama Sebagai instansi pemerintah yang Menerapkan Pola Pengelolaan Keuangan Badan Layanan Umum.

Peraturan Menteri Pendidikan Dan Kebudayaan Republik Indonesia Nomor 93 Tahun 2014. Tentang Tata Cara Penetapan Standar Satuan Biaya Operasional Pendidikan Tinggi Pada Perguruan Tinggi Negeri Badan Hukum.

Peraturan Pemerintah Nomor 23 Tahun 2005 tentang Pengelolaan Keuangan Badan Layanan Umum.

Peraturan Pemerintah No. 33 Tahun 1990. Tentang Pendidikan Tinggi.

Peraturan Pemerintah Nomor 74 Tahun 2012 tentang Pengelolaan Keuangan Badan Layanan Umum. 
Peraturan Presiden No. 35 Tahun 2017. Tentang Universitas Islam Negeri Imam Bonjol Padang.

Riwayadi. 2014. Akuntansi Biaya Pendekatan Tradisional dan Kontemporer. Jakarta: Salemba Empat.

Sekaran, Uma. 2017. Research Methods For Business, Metodologi Penelitian untuk Bisnis. Edisi 6 Buku 1. Jakarta: Salemba Empat.

Setiaji. 2008. Analisis Biaya Pelayanan Rawat Inap Diruang VIP Cendrawasih RAUD Soesselo Tegal. Tesis. Universitas Diponegoro.Semarang.

Undang-Undang Nomor 1 tahun 2004. Tentang Perbendaharaan Negara.

Undang-Undang No 17 tahun 2003, Tentang Keuangan Negara.

Undang-Undang Nomor 12 Tahun 2012. Tentang Pendidikan Tinggi.

Ismail, Noor Azizi, 2010, Activity based management syste, implementation in higher education institution, Campus Wide Information Systems Vol.27 No.1. 